\title{
Applying Nanotechnology in the Synthesis of Benzimidazole Derivatives: A Pharmacological Approach
}

\author{
Ahmed A. El-Sayed ${ }^{1 \mathbb{D}}$, Sherifa M. Abu-Bakr ${ }^{2}{ }^{\mathbb{D}}$, Samira A. Swelam ${ }^{1 \mathbb{D}}$, Nahid Y. Khaireldin ${ }^{1 \mathbb{D}}$, Kamel \\ R. Shoueir ${ }^{3,4}$ (D), Ahmed M. Khalil 1, * (D) \\ Photochemistry Department, National Research Centre, 33 El-Bohouth St., Dokki - 12622, Giza, Egypt \\ 2 Department of Chemistry of Natural and Microbial Products, Division of Pharmaceutical and Drug Industries, National \\ Research Centre, Dokki, Cairo, Egypt \\ 3 Institute of Nanoscience \& Nanotechnology, Kafrelsheikh University, 33516 Kafrelsheikh, Egypt \\ 4 Institut de Chimie et Procédés pour l'Énergie, l'Environnement et la Santé (ICPEES), CNRS UMR 7515-Université de \\ Strasbourg, 25 rue Becquerel 67087 Strasbourg, France \\ * Correspondence: akhali175@yahoo.com;
}

Scopus Author ID 55605778944

Received: 4.03.2021; Revised: 10.04.2021; Accepted: 14.04.2021; Published: 26.04.2021

\begin{abstract}
Benzimidazoles are classified as a category of heterocyclic compounds. They possess an essential structural feature of 6-membered benzene fused to 5-membered imidazole moiety. Molecules having benzimidazole motifs confirmed promising utility in organic and scientific studies. Various pharmacological residences were explored with a strong inhibitor of numerous enzymes. They are concerned with being efficient antidiabetic, anticancer, antimicrobial, antiparasitic, analgesics, antiviral and antihistaminic agents. Moreover, they can be utilized in cardiovascular disease, neurology, endocrinology, and ophthalmology. The multiple activities for benzimidazole compounds have emerged due to their stability, bioavailability, and good-sized organic activity. Modifications of some organic polymers were carried out by utilizing different azole moieties. This review is devoted to mention some of the various current techniques for the synthesis of benzimidazole derivatives and their pharmacological residences with representing numerous derivatives.
\end{abstract}

Keywords: benzimidazole; medicinal chemistry; nanocatalysis; nanoparticles; nanotechnology; polymer modification.

(C) 2021 by the authors. This article is an open-access article distributed under the terms and conditions of the Creative Commons Attribution (CC BY) license (https://creativecommons.org/licenses/by/4.0/).

\section{Introduction}

Benzimidazole or 1H-1,3-benzodiazole primarily based heterocycles are structurally much like evidently taking the place of nucleotides, i.e., adenine base of the DNA [1-3]. This is regarded in addition to a factor of vitamin B. This feature substantially has been utilized in drug synthesis and medicinal chemistry, showing a huge variety of organic and scientific applications. Benzimidazole is also named 3-azaindole, azindiole, benzimiinazole, benzoglyoxine. Benzimidazole is a vital modified structure that presents an extensive number of natural and pharmacologically active molecules. Magnetic nanoparticles (MNPs) have emerged as a new category of catalysts. This is referred to as ultrafine size and high surface area. They exhibit a better catalytic activity than a conventional heterogeneous catalyst. In general, there are artificial approaches for the synthesis of benzimidazole derivatives. The synthesized benzimidazole compounds have been organized from the condensation response between o-phenylenediamine and diverse carbonyl compounds. This process is carried out in the presence of ammonium chloride as a catalyst. Ammonium chloride is a commercial 
catalyst. The yield of all benzimidazole derivatives turned to be 75-94\% [4-7]. A condensation reaction takes place between o-phenylenediamine and aldehydes or alcohols. This occurs through a dehydrogenated coupling followed by an oxidative cyclodehydrogenation $[8,9]$. Nevertheless, in some of those methods, a stoichiometric quantity of oxidizing marketers is a prerequisite $[10,11]$. Other strategies, along with thermal- or acid-promoted synthesis in addition to microwave, sonicator, or ultrasound strategies, are also known [8]. Interestingly, the direct regioselective C-2 arylation of imidazole with aryl halides generally calls for the usage of a $\mathrm{Pd}(\mathrm{II}) / \mathrm{Cu}(\mathrm{I}) / \mathrm{Au} / \mathrm{TiO}_{2}$ catalytic machine in a surplus of reagents beside the presence of additives, excessive temperature, or pressure $[12,13]$. Benzimidazoles can easily interact with the biopolymers of the dwelling systems, which are chargeable for their several organic functions. In particular, benzimidazole derivatives showcase antimicrobial [14-16], antiviral [13, 17], anticancer [18-20], anti-inflammatory [21-23] and antioxidant [24] agents. Meanwhile, numerous derivatives were evolved as healing agents, inclusive of proton pump inhibitors [25], stage modulators [26], and antidiabetics [27, 28]. Recently, Benzimidazole derivatives were used in the modification of polymers such as nanostructured poly(benzimidazole) membranes [29], poly(imides), and poly(imides)/ionic liquid composites using a benzimidazole moiety [30]. The best advantage of magnetic nanoparticles is their easy separation from the reaction mixture using an external magnet.

In this article, we attempt to demonstrate the structures of some of the medicinally and biologically important benzimidazole and benzodiazepine derivatives accordingly. It is a study to cover conventional and new methods to synthesize certain pharmacologically active benzimidazole derivatives and different methods of building the benzimidazole nucleus.

\section{Application of Nanotechnology in the Syntheses of Benzimidazole Derivatives}

Practically, all benzimidazoles synthesis methods start with benzene derivatives possessing nitrogen-containing functions ortho to each other [31, 32]. Among the various MNPs employed as the catalyst, $\mathrm{Fe}_{3} \mathrm{O}_{4}-\mathrm{NPs}$ are mentioned. It has been widely studied due to high surface area to bulk ratio, low toxicity, high activity, thermal stability, and surface modification capability with as easy dispersion [33-38]. A plausible mechanism for the model of benzimidazole synthesis is presented in Figure 1. $\mathrm{Fe}_{3} \mathrm{O}_{4}-\mathrm{NPs}$ as Lewis acid catalyst may invigorate the carbonyl group of aldehyde. Hence, this leads to an increase in the carbon atom's electrophilic character in the carbonyl group with lowering the transition state energy. It was followed by the attack of an amino group from I-phenylenediamine on the activated carbonyl group that resulted in an imine. The present $\mathrm{NH}_{2}$ group in $o$-phenylenediamine is attacked by a carbon atom $\mathrm{C}=\mathrm{N}$ group. This is followed by producing a proton that attracts the catalyst particles so that they can recover easily. The recovered $\mathrm{Fe}_{3} \mathrm{O}_{4}-\mathrm{NPs}$ were placed in ethanol and dried at $60{ }^{\circ} \mathrm{C}$ [39]. A green and efficient method for synthesizing Benzimidazole compounds was followed using $\mathrm{Fe}_{3} \mathrm{O}_{4}-\mathrm{NPs}$ with the continuous bubbling of air as the oxidant in PEG$400 / \mathrm{H}_{2} \mathrm{O}$ aqueous solution at room temperature [40].

An effective and selective synthesis for 1, 2-disubstituted benzimidazole and 1, 5benzodiazepine derivatives was performed using 1, 2-diamines and aldehydes or ketones. This process was carried out in the presence of catalytic and magnetically recoverable chitosansupported iron oxide nanoparticles $\left(\mathrm{Fe}_{3} \mathrm{O}_{4} /\right.$ chitosan). This nanocomposite as a biodegradable one was immersed in ethanol at high ambient yields. The $\mathrm{Fe}_{3} \mathrm{O}_{4} /$ chitosan nanocatalyst can be recovered easily and reused without any significant loss of the catalytic activity [41]. This 
procedure takes place in the presence of mechano-chemically synthesized zinc oxide nanoparticles as a catalyst without solvent [42].

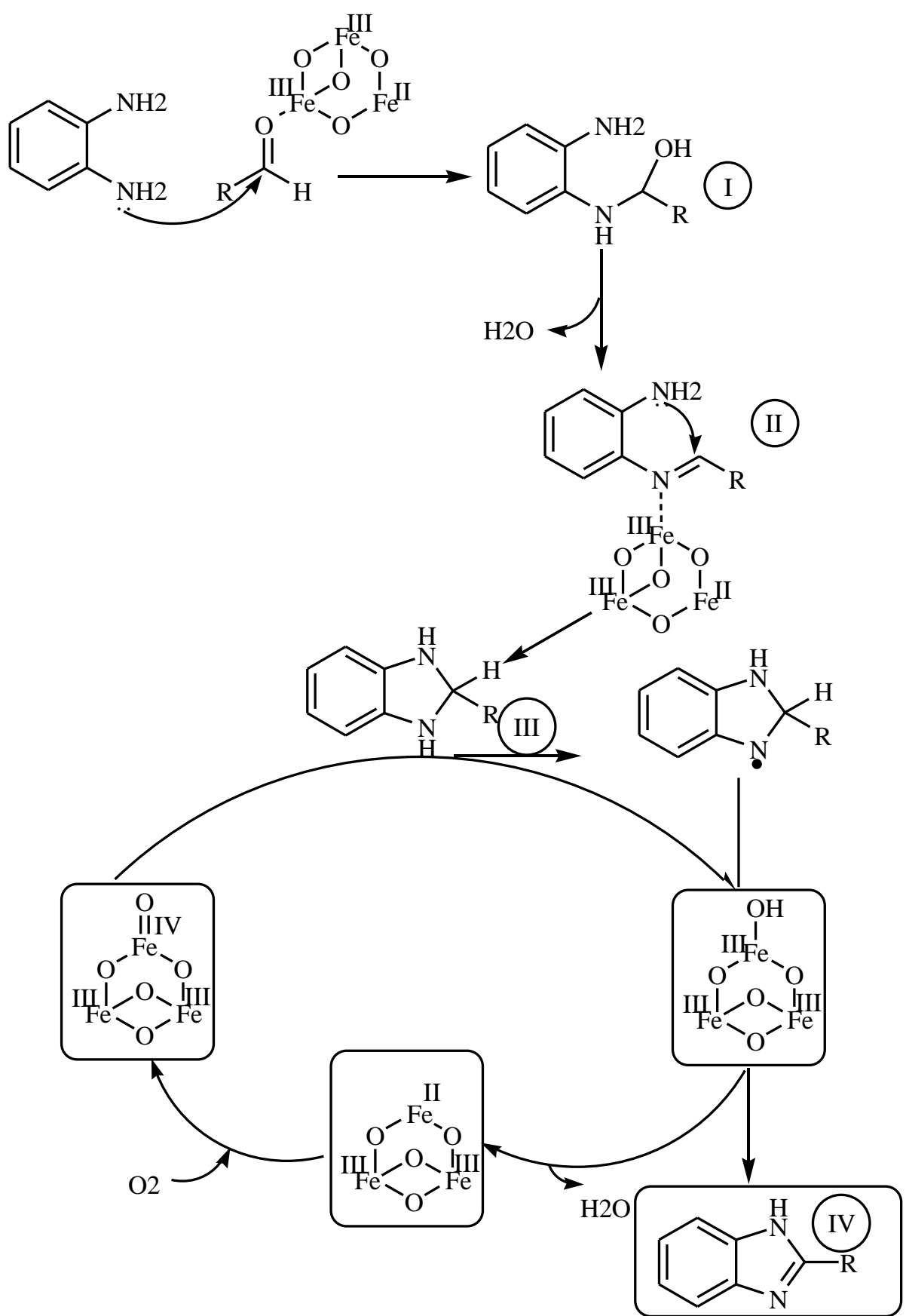

Figure 1. Mechanism of synthesizing benzimidazoles, catalyzed by $\mathrm{Fe}_{3} \mathrm{O}_{4}-\mathrm{NPs}$.

A series of 2,4,5-trisubstituted imidazoles and 1,2-disubstituted Benzimidazoles catalyst by $\mathrm{ZrO}_{2}$ nanoparticles- supported $\beta$-cyclodextrin nanoparticles $\left(\mathrm{ZrO}_{2}-\beta C D\right)$ was prepared by a simple one-pot co-precipitation method by using $\mathrm{ZrO} \mathrm{Cl}_{2} .8 \mathrm{H}_{2} \mathrm{O}$ and $\mathrm{NH}_{4} \mathrm{OH}$ [43]. The high electrocatalytic activity of a composite, formed by supporting $\mathrm{Ni}_{3} \mathrm{~N}$ nanoparticles on benzimidazole covalent organic frame (COF) for oxygen evaluation reaction, was achieved [43]. The syntheses of $\mathrm{COF}$ and its nanocomposite were achieved via reacting 3,3' - diaminobenidine and 1,3,5-triformyl phloroglucinol in a mixture of mesitylene and 1,4dioxan. IISERP-COF3-Ni $3 \mathrm{~N}$ was prepared by loading nickel nitride nanoparticles onto the COF via a solid-state synthesis, as displayed in Figure 2. 


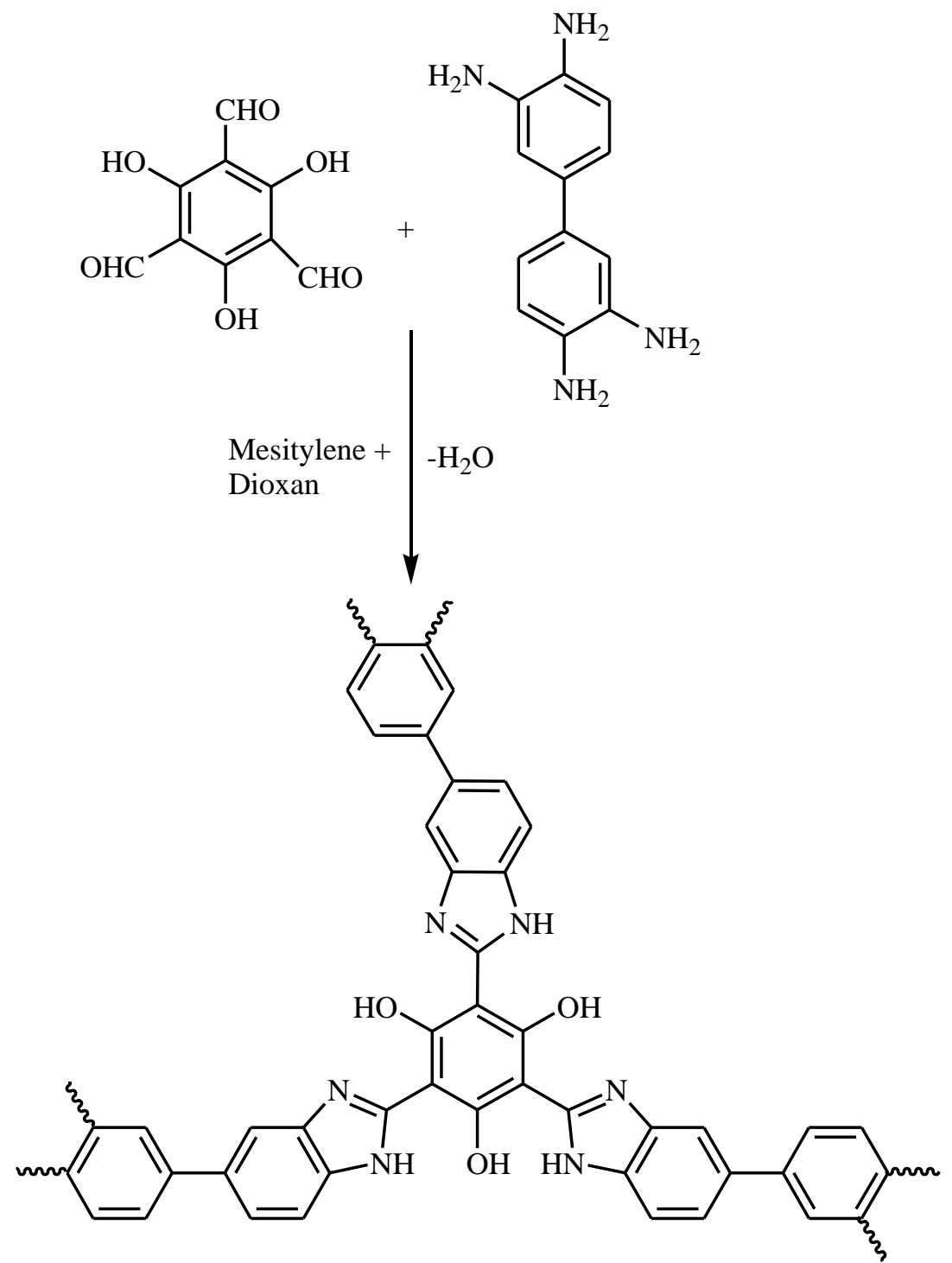

Figure 2. A co-precipitation method to prepare benzimidazoles by using $\mathrm{ZrOCl}_{2}, 8 \mathrm{H}_{2} \mathrm{O}$ then by using nickel nitride nanoparticles, respectively.

Some azoles and azido derivatives [44-47] were loaded to organic polymers and metal nanoparticles [48, 49], showing antimicrobial activities. Besides, chitosan [50-53] is considered among the common polymers that can bear biomedical agents. Heterocyclic aromatic polymers are considered among the high-performance materials. They possess high chemical resistance, flame retardancy, radiation stability, and excellent mechanical strength over a broad temperature range [54]. The structure of poly-benzimidazole (PBI) nanofibers resembled that of a nonwoven fabric. These fibers were formed by the precipitation of oligoimida-zoles and their subsequent polymerization with the developing crystal structure. The nanofibers exhibited excellent thermal stability. The monomer's form affected the reactioninduced phase separation participates in making variations in the morphology of the precipitates. The monomer structure is a vital factor that controls the morphology. Benaimidazol-2-ylidienes with gold nanoparticles (AuNPs) were studied as reactive compounds. A collective experimental and computational approach was employed [55]. Grafting of benimidazol-2-ylidenes with benzyl groups on the nitrogen atom was depicted. This was followed by comparing structurally similar N-heterocyclic carbenes (NHCs) loaded with another $\mathrm{N}$ - group. A significant reactivity was noticed for all NHC. However, eroding AuNPs has occurred under the NHC effect with originated bis(NHC) gold complexes. DFT 
calculations examined the modes of grafting of such ligands by defining the absorption energies.

Benzimidazole derivatives were synthesized by using Copper (II) oxide (CuO) nanoparticles. Copper (II) oxide ( $\mathrm{CuO}$ ) nanoparticles were prepared through a facile precipitation procedure to copper acetate. The produce nanoparticles asserted to act as an effective catalyst for $\mathrm{C}-\mathrm{N}$ coupling reactions of benzimidazole with arylhalides [56]. The influence of the particle size on $\mathrm{N}$-arylation of benzimidazole with 4-chlorobenzonitrile was investigated.

\section{Some Pharmacological Aspects of Benzimidazole and Substituted Benzimidazoles}

Various chemical modifications were carried out so far around the benzimidazole backbone (core) to improve its various biological activities. Benzimidazoles have emerged as an important heterocyclic compound because of their broad spectrum of biological activities. In this review, anti-inflammatory, anthelmintic, anticancer, and antiviral activities of benzimidazole and its derivatives are determined.

\subsection{Antiviral and antitumor activities}

The antiviral properties of different benzimidazole derivatives have been reported in a variety of studies using different virus strains, such as human immunodeficiency virus (HIV) [57-61], hepatitis C virus (HCV) [62-69], human cytomegalovirus (HCMV) [70-74] and herpes simplex virus-1 (HSV-1) [75].

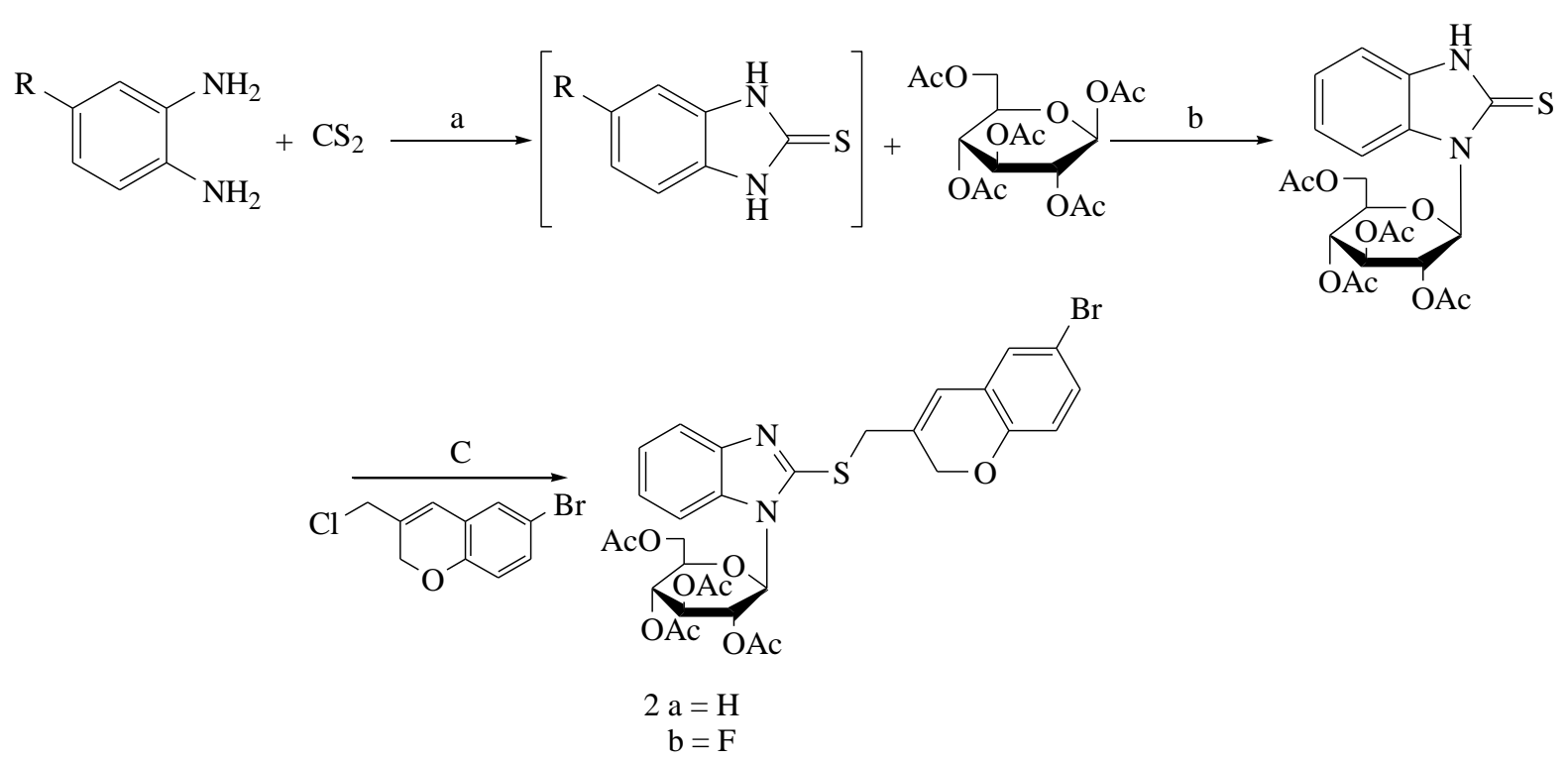

Figure 3. Synthesis of some benzimidazole derivatives with antiviral activities. Reagents and conditions: (a) $\mathrm{KOH} / \mathrm{EtOH} / \mathrm{H}_{2} \mathrm{O}$. (b) $\mathrm{BSA} / \mathrm{Me}_{3} \mathrm{SiOTf} / \mathrm{CH}_{3} \mathrm{CN} / 80^{\circ} \mathrm{C}$. (c) $35 \% \mathrm{NH}_{4} \mathrm{OH} / \mathrm{CH}_{3} \mathrm{CN} / \mathrm{H}_{2} \mathrm{O}$ (at $25^{\circ} \mathrm{C}$ ).

A series of 1 -aryl- $1 H, 3 H$-thiazolo[3,4-a] benzimidazoles (TBZs) was found to be highly active as HIV-1 non-nucleoside reverse transcriptase inhibitors (NNRTIs) [57, 58]. 1(2,6-difluorophenyl)-1H,3H-thiazolo [3,4-a] benzimidazole (TBZ, NSC 625487) manifested to be an efficient inhibitor for HIV-1 induced cytopathic effect [59-62]. Several new benzimidazole-coumarin conjugates showed an inhibitory effect on HCV replication; some compounds were synthesized according to Figure 3 and showed EC50 values of $3.4 \mu \mathrm{M}$ and 4.1 $\mu \mathrm{M}$, respectively [62]. 
A series of 1-cycloalkyl-2-[(4-diarylmethoxy)phenyl]-benzimidazole-5-carboxylic acid derivatives were reported to have inhibitory activity against hepatitis $\mathrm{C}$ virus NS5B RNAdependent RNA polymerase (HCV NS5B RdRp). The synthesized compounds were found to have, in addition to their RNA polymerase inhibitory activity, selective activity against DNA polymerases with low cytotoxicity was also observed [63]. A new investigated series of benzimidazole derivatives bearing a diarylmethylene group was tested for its inhibitory activity against HCV NS5B RdRp. These compounds exhibited favorable pharmacokinetic profiles, high selectivity for NS5B polymerase, and good safety profiles, suggesting the potential for a clinical candidate to treat hepatitis $\mathrm{C}[64,65]$. Some benzimidazole-5-carboxylic acid derivatives were detected to specifically inhibit HCV NS5B RdRp and regarded as potent compounds [66] for such purpose. Optimizing the previously discovered series of substituted5-carboxybenzimidazole by replacing the ionizable carboxylic acid with neutral substituents modified their physicochemical properties and increased their cellular permeability. Modification to one of these compounds improved cell culture activity and was not cytotoxic to the host cells [67-59]. 2-Bromo-5,6-dichloro-1-( $\beta$-D-ribofuranosyl)benzimidazole (BDCRB) and its 2-chloro analog (TCRB) were determined as efficient and selective inhibitors of HCMV replication. However, these compounds were found to have low in vivo activity due to rapid metabolic cleavage of the glycosidic linkage at the 1-position [70]. Efforts were exerted to overcome the limitation above. It led to the discovery of Maribavir, (GW1263W94). This compound was one of the most promising anti-HCMV drugs in clinical development. It showed advantages over other existing anti-HCMV drugs in their in vitro potency, bioavailability, the safety profile in acute, chronic, and genetic toxicology testing. Meanwhile, the lack of crossresistance is inherent in its novel mechanism of action, which involves inhibiting viral DNA synthesis $[70,72]$.

Several benzimidazole nucleosides and acyclonucleosides have been studied for their antiviral activity against HCMV and HSV-1. Only the 2-thiobenzyl analogs showed high activity, confirming the favorable influence of the thioether linkage at the 2-position on the antiviral activity $[36,37]$. Some $N$-benzene-sulphonyl-benzimidazoles were reported to have good antiviral activity against HCMV and HSV-1 at micromolar concentrations [75-78]. A series of 2-pyridyl-1 $H$-benzimidazole-4-( $N$-substituted-carboxamide) derivatives was found to have excellent inhibitory activity against Coxsackie virus B3. They were synthesized and explored to be far more active than ribavirin [78]. Studying the 2-substituted-5-amidinobenzimidazoles antiviral activity revealed that compounds having a pyridine moiety at $\mathrm{C}-2$ showed the most distinct and selective activity against coxsackieviruses and echoviruses [77]. Enviroxime compounds exhibited potent broad-spectrum anti-rhinovirus and anti-enterovirus activity. Preliminary studies indicated that their action mechanism involves inhibition of viral RNA synthesis [77-80]. 1-Cyclopropyl-1,3-dihydro-3-[[1-(4-hydroxybutyl)-1H-benzimidazol2-yl)methyl]-2H-imidazo[4,5-c]pyridin-2-one, (BMS-433771) is determined as an efficient respiratory syncytial virus (RSV) inhibitor showing acceptable oral bioavailability [81-85]. The benzimidazole derivative (JNJ 2408068) or known as (R170591), was discovered to have inhibitory activity against RSV at nanomolar concentration, which was about 100,000 times better than that of ribavirin [86]. Recently, 2,6-dihalophenyl-substituted- $1 H, 3 H$-thiazolo[3,4a]benzimidazo-les (TBZs) were tested against enteroviruses. The structure-activity analysis detected that the substituents at position 6 of the tricyclic system positively affect antiviral activity. Hence, any substitution at position 7 was not recommended. Meanwhile, it was not cytotoxic at high concentrations [87]. Several promising antitumor active agents were found to 
contain the benzimidazole ring system. They were explored to exert their antitumor activity by acting mainly as topoisomerase inhibitors [88-92], alkylating agents [17, 93-96], antiangiogenic agents [97-101], and protein kinase inhibitors [102-107]. A series of benimidazol-furanhybrids was designed and synthesized through synthetic facial pathways and evaluated in vitro cytotoxic activity against breast (MCF-7) and hepatocellular (HepG2) carcinoma cell lines [108].

\subsection{Alkylating and antiangiogenic agents.}

Pyrrolo[1,2-a]benzimidazoles-4,7-dione (PBIs) derivatives represented a different class of antitumor agents exhibiting cytotoxic activity against various cancer cell lines. Their mechanism of cytotoxicity involves $\mathrm{N}$ (7) purine alkylation followed by depurination and backbone cleavage at the guanine and adenine bases. It was determined that the presence of an ester group at the 3-position was required for optimal cytotoxicity because it provides lipophilicity [17, 91-95]. A series of 2-substituted benzimidazole-4,7-dione was synthesized and evaluated for its cytotoxic activity. They succeeded in showing excellent cytotoxic activity comparable to that of mitomycin C [96]. Angiogenesis expressing the formation of new blood vessels from existing vasculature was considered a critical event for the growth and metastasis of solid tumors. Growth factors, including vascular endothelial growth factor, fibroblast growth factor, and platelet-derived growth factor, are considered the most important positive regulators of angiogenesis. So, any inhibitor showing these growth factors and their tyrosine kinase receptors drew the attention of potent anticancer drugs [109]. These receptors comprise platelet-derived growth factor receptor (PDGFR) and insulin-like growth factor receptor-1 (IGF-1R). A class of 1-phenylbenzimidazoles was reported as a selective inhibitor of PDGFR. The structure-activity relationship revealed that only substituents in the 5-and 6-positions enhance the activity. 5-OMe derivative was found to be the most potent and the most PDGFR selective. In addition, analogs bearing cationic solubilizing groups at this position showed 3fold increased potency with retaining good selectivity [97-98]. A series of 3-(1Hbenzo[ $d]$ imidazol-2-yl)pyridin-2(1H)-one was synthesized and tested for its inhibitory activity against IGF-1R. Although some compounds were found to have high inhibitory activity, potent cytochrome P450 (CYP) inhibition profiles were also observed. Results described have demonstrated that the pendant imidazole was primarily responsible for potent (CYP) inhibition. By replacing this moiety with other groups such as imidazoline, greater separation of IGF-1R activity versus (CYP) inhibition was observed [99]. Benzimidazole derivatives containing styryl sulfone moiety at the 2-position were tested for their antiproliferative activity. Some of the synthesized compounds showed efficacy against HT-29 human carcinoma inhibiting 51\% of the tumor growth at low micromolar concentration [110]. A series of 2-methyl-5(6)-nitro$1 H$-benzimidazole derivatives was synthesized and evaluated for their cytotoxic activity against breast cancer (MCF7). Among this series, two compounds were found to have high cytotoxic activity [111]. A series of 2-(1-benzyl-2-methyl- $1 H$-benzimidazol-5-ylimino)-3(substituted)-thiazolidin-4-ones was synthesized and evaluated for its inhibitory activity against Burkitt's lymphoma promotion to show significant inhibitory activity [112].

\section{Conclusions}

Benzimidazole derivatives are among the most important heterocyclic compounds. This may be because they are much like evidently taking place nucleotides. This review highlights 
the importance of using nanotechnology to synthesize benzimidazoles as anticancer agents with their diverse biological profiles. Being commercially derived in very sort of therapeutic agents, this review can facilitate chemists designing novel compounds. This approach is comprised in the frame of synthesizing highly active biological compounds against cancer cells alongside being antifungal and bacterial agents. Moreover, this review refers to polymer modification by using azole compounds. We aimed to point out some contemporary applied techniques to synthesize the benzimidazole derivatives. Moreover, their pharmacological potencies with representing numerous derivatives are monitored.

\section{Funding}

This research received no external funding.

\section{Acknowledgments}

This research has no acknowledgment.

\section{Conflicts of Interest}

The authors declare no conflict of interest.

\section{References}

1. El-Sayed, A.A.; Pedersen, E.B.; Khaireldin, N.Y. Thermal Stability of Modified i-Motif Oligonucleotides with Naphthalimide Intercalating Nucleic Acids. Helv. Chim. Acta. 2016, 99, 14-19, https://doi.org/10.1002/hlca.201500140.

2. El-Sayed, A.A.; Pedersen, E.B.; Khaireldin, N.A. Studying the influence of the pyrene intercalator TINA on the stability of DNA i-motifs, Nucleosides. Nucleotides and Nucleic Acids. 2012, 31, 872-879, https://doi.org/10.1080/15257770.2012.742199.

3. El-Sayed, A. A.; Molina, T. A.; Álvarez-Ros, M.C.C.; Palafox Alcolea, M. Conformational analysis of the anti-HIV Nikavir prodrug: Comparisons with AZT and Thymidine, and establishment of structure-activity relationships/tendencies in other 6'-derivatives. J. Biomol. Struct. Dyn. 2015, 33, 723-748, https://doi.org/10.1080/07391102.2014.909743.

4. Kamanna, K. Synthesis and Pharmacological Profile of Benzimidazoles. Chem. Appl. Benzimidazole Its Deriv. IntechOpen 2019, https://doi.org/10.5772/intechopen.85229.

5. Pardeshi, V.A.S.; Chundawat, N.S.; Pathan, S.I.; Sukhwal, P.; Chundawat, T.P.S.; Singh, G.P. A review on synthetic approaches of benzimidazoles. Synth. Commun. 2020, 1-29, https://doi.org/10.1080/00397911.2020.1841239.

6. Dege, N.S.; Sekerc, I.; Serv, S.I. Structure of 1-(Thiophen-2-ylmethyl)-2-(thiophen-2-yl)-1Hbenzimidazole. Turk J Chem. 2006, 30.

7. Karimi, B.; Mansouri, F.; Mirzaei, H.M. Recent Applications of Magnetically Recoverable Nanocatalysts in C-C and C-X Coupling Reactions. ChemCatChem. 2015, 7, 1736-1789, https://doi.org/10.1002/cctc.201403057.

8. Alaqeel, S.I. Synthetic approaches to benzimidazoles from o-phenylenediamine: A literature review. J. Saudi Chem. Soc. 2017, 21, 229-237, https://doi.org/10.1016/j.jscs.2016.08.001.

9. Panda, S.; Malik, R.; Jain, S.C. Synthetic Approaches to 2-Arylbenzimidazoles: A Review. Curr. Org. Chem. 2012, 16, 1905-1919, https://doi.org/10.2174/138527212802651232.

10. Bahrami, K.; Mehdi Khodaei, M.; Naali, F. Mild and highly efficient method for the synthesis of 2arylbenzimidazoles and 2-arylbenzothiazoles. J. Org. Chem. 2008, 73, 6835-6837, https://doi.org/10.1021/jo8010232.

11. Karami, C.; Ghodrati, K.; Izadi, M.; Farrokh, A.; Jafari, S.; Mahmoudiyani, M.; Haghnazari, N. A fast procedure for the preparation of benzimidazole derivatives using polymer-supported with trifluoromethanesulfonic acid as novel and reusable catalyst. J. Chil. Chem. Soc. 2013, 58, 1914-1917, https://doi.org/10.4067/S0717-97072013000300026.

12. Bellina, F.; Benelli, F.; Rossi, R. Direct palladium-catalyzed C-3 arylation of free (NH)-indoles with aryl bromides under ligandless conditions. J. Org. Chem. 2008, 73, 5529-5535, https://doi.org/10.1021/jo8007572. 
13. Tzani, M.A.; Gabriel, C.; Lykakis, I.N. Selective synthesis of benzimidazoles from o-phenylenediamine and aldehydes promoted by supported gold nanoparticles. Nanomaterials. 2020, 10, 1-17, https://doi.org/10.3390/nano10122405.

14. Andrzejewska, M.; Yepez-Mulia, L.; Tapia, A.; Cedillo-Rivera, R.; Laudy, A.E.; Starościak, B.J.; Kazimierczuk, Z. Synthesis, and antiprotozoal and antibacterial activities of S-substituted 4,6-dibromo- and 4,6-dichloro-2-mercaptobenzimidazoles. Eur. J. Pharm. Sci. 2004, 21, 323-329, https://doi.org/10.1016/j.ejps.2003.10.024.

15. Bansal, Y.; Kaur, M.; Bansal, G. Antimicrobial potential of benzimidazole derived molecules. Mini Rev. Med. Chem. 2019, 19, 624-46, https://doi.org/10.2174/1389557517666171101104024.

16. Vasava, M.S.; Bhoi, M.N.; Rathwa, S.K.; Jethava, D.J.; Acharya, P.T.; Patel, D.B. Patel, H.D. Benzimidazole: A milestone in the field of medicinal chemistry. Mini Rev. Med. Chem. 2020, 20, 532-565, https://doi.org/10.2174/1389557519666191122125453.

17. Gellis, A.; Kovacic, H.; Boufatah, N.; Vanelle, P. Synthesis and cytotoxicity evaluation of some benzimidazole-4,7-diones as bioreductive anticancer agents. Eur. J. Med. Chem. 2008, 43, 1858-1864, https://doi.org/10.1016/j.ejmech.2007.11.020.

18. Purushottamachar, P.; Ramalingam, S.; Njar, V.C.O. Development of Benzimidazole Compounds for Cancer Therapy. Chem. Appl. Benzimidazole Its Deriv. IntechOpen 2019, https://doi.org/10.5772/intechopen.86691.

19. Akkoç, S. Antiproliferative activities of 2-hydroxyethyl substituted benzimidazolium salts and their palladium complexes against human cancerous cell lines. Synth. Commun. 2019, 49, 2903-2914, https://doi.org/10.1080/00397911.2019.1650187.

20. Atmaca, H.; İlhan, S.; Batır, M.B.; Pulat, Ç.Ç.; Güner, A.; Bektaş, H. Novel benzimidazole derivatives: Synthesis, in vitro cytotoxicity, apoptosis and cell cycle studies. Chem. Biol. Interact. 2020, 327, https://doi.org/10.1016/j.cbi.2020.109163.

21. Labanauskas, L.K.; Brukštus, A.B.; Gaidelis, P.G.; Buchinskaite, V.A.; Udrenaite, É.B.; Daukšas, V.K. Synthesis and anti-inflammatory activity of some new 1-acyl derivatives of 2-methylthio-5,6diethoxybenzimidazole. Pharm. Chem. J. 2004, 34, 353-355, https://doi.org/10.1023/A:1005213306544.

22. Ganji, L.V.; Agrawal, P.N. Design, synthesis and anti-inflammatory evaluation of 5 (6)-(un)-substituted-1Hbenzimidazol-2-ylthioacetylpiperazine derivatives. Indian J. Pharm. Sci. 2020, 82, 21-31, https://doi.org/10.36468/pharmaceutical-sciences.619.

23. Ito, K.; Kagaya, H.; Satoh, I.; Tsukamoto, G.; Nose, T. The studies of the mechanism of antiinflammatory action of 2-(5-ethylpyridin-2-yl)benzimidazole (KB-1043). Arzneimittel-Forschung/Drug Res. 1982, 32, 117-122.

24. Can-Eke, B.; Puskullu, M.O.; Buyukbingol, E.; Iscan, M. A study on the antioxidant capacities of some benzimidazoles in rat tissues. Chem. Biol. Interact. 1998, 113, 65-77, https://doi.org/10.1016/S00092797(98)00020-9.

25. Narasimhan, B.; Sharma, D.; Kumar, P.; Benzimidazole: A medicinally important heterocyclic moiety. Med. Chem. Res. 2012, 21, 269-283, https://doi.org/10.1007/s00044-010-9533-9.

26. Powell, D.A.; Ramtohul, Y.; Lebrun, M.E.; Oballa, R.; Bhat S.; Falgueyret J. P.; Guiral S.; Huang Z.; Skorey K.; Tawa P.; Zhang L. 2-Aryl benzimidazoles: Human SCD1-specific stearoyl coenzyme-A desaturase inhibitors. Bioorg. Med. Chem. Lett. 2010, 20, 6366-6369, https://doi.org/10.1016/j.bmcl.2010.09.094.

27. Shingalapur, R.V.; Hosamani, K.M.; Keri, R.S.; Hugar, M.H. Derivatives of benzimidazole pharmacophore: Synthesis, anticonvulsant, antidiabetic and DNA cleavage studies. Eur. J. Med. Chem. 2010, 45, 1753-1759, https://doi.org/10.1016/j.ejmech.2010.01.007.

28. Ishikawa, M.; Nonoshita, K.; Ogino, Y.; Nagae, Y.; Tsukahara, D.; Hosaka, H.; Maruki, H.; Ohyama, S.; Yoshimoto, R.; Sasaki, K.; Nagata, Y.; Eiki, J. ichi, Nishimura, T. Discovery of novel 2-(pyridine-2-yl)-1Hbenzimidazole derivatives as potent glucokinase activators. Bioorganic Med. Chem. Lett. 2009, 19, 44504454, https://doi.org/10.1016/j.bmcl.2009.05.038.

29. Dominguez, P.; Grygiel, K.; Weber, J. Nanostructured poly(benzimidazole) membranes by N-alkylation. Express Polym. Lett. 2014, 8, 30-38, https://doi.org/10.3144/expresspolymlett.2014.4.

30. Terraza, C.A.; Ortiz P.; Tagle, L.H.; Saldias, C.; Rodr, F.E.; Cabrera-barjas, G.; Catal, H. Tundidor-camba A.; Coll D. Poly ( imides ) / Ionic Liquid Composites Bearing a Benzimidazole Moiety. Polymers (Basel) 2019, 11 .

31. Ranganath, K.V.S.; Glorius, F. Superparamagnetic nanoparticles for asymmetric catalysis - A perfect match. Catal. Sci. Technol. 2011, 1, 13-22, https://doi.org/10.1039/c0cy00069h.

32. Ghorbani-Choghamarani, A.; Shiri, L.; Azadi, G. The first report on the eco-friendly synthesis of 5substituted 1: $\mathrm{H}$-tetrazoles in PEG catalyzed by $\mathrm{Cu}(\mathrm{ii})$ immobilized on $\mathrm{Fe}_{3} \mathrm{O}_{4} @ \mathrm{SiO}_{2} @$ 1-arginine as a novel, recyclable and non-corrosive catalyst. $R S C A d v$. 2016, 6, 32653-32660, https://doi.org/10.1039/c6ra03023h.

33. Sajjadi, A.; Mohammadi, R. Fe3O4 magnetic nanoparticles (Fe3O4 MNPs): A magnetically reusable catalyst for synthesis of Benzimidazole compounds. J. Med. Chem. Sci. 2019, 2, 55-58, https://doi.org/10.26655/jmchemsci.2019.3.4.

34. Cahyana, A.H.; Ardiansah, B.; Asrianti, N.A. $\mathrm{Fe}_{3} \mathrm{O}_{4}$ nanoparticles: An efficient and recyclable catalyst for benzimidazoles synthesis articles you may be interested in $\mathrm{Fe}_{3} \mathrm{O}_{4} @$ chitosan nanoparticles promoted a convenient condensation of cinnamaldehyde with dimedone AIP Conference $\mathrm{Fe}_{3} \mathrm{O}_{4}$ Nanoparticles: An 
Efficient and Recyclable Catalyst for Benzimidazoles Synthesis. AIP Conference Proceedings 2018, 2023, https://doi.org/10.1063/1.5064058.

35. Wang, Z.; Zhu, J.; Zhu, Z.; Xu, J.; Lu, M. A green and efficient method for synthesis of benzimidazoles using nano $\mathrm{Fe}_{3} \mathrm{O}_{4}$ in $\mathrm{PEG} 400 / \mathrm{H}_{2} \mathrm{O}$ aqueous system under ambient conditions at room temperature. Appl. Organomet. Chem. 2014, 28, 436-440, https://doi.org/10.1002/aoc.3145.

36. Sajjadi, A.; Mohammadi, R. $\mathrm{Fe}_{3} \mathrm{O}_{4}$ magnetic nanoparticles $\left(\mathrm{Fe}_{3} \mathrm{O}_{4} \mathrm{MNPs}\right)$ : A magnetically reusable catalyst for synthesis of Benzimidazole compounds. J. Med. Chem. Sci. 2018, 2, 55-58.

37. Maleki, A.; Ghamari, N.; Kamalzare, M. Chitosan-supported Fe3O4 nanoparticles: A magnetically recyclable heterogeneous nanocatalyst for the syntheses of multifunctional benzimidazoles and benzodiazepines. RSC Adv. 2014, 4, 9416-9423, https://doi.org/10.1039/c3ra47366j.

38. Singhal, S.; Khanna, P.; Panda, S.S.; Khanna, L. Recent Trends in the Synthesis of Benzimidazoles From oPhenylenediamine via Nanoparticles and Green Strategies Using Transition Metal Catalysts. J. Heterocycl. Chem. 2019, 56, 2702-2729, https://doi.org/10.1002/jhet.3649.

39. Girish, Y.R.; Kumar, K.S. S.; Thimmaiah, K.N.; Rangappa, K.S.; Shashikanth, S. ZrO ${ }_{2}-\beta$-cyclodextrin catalyzed synthesis of 2,4,5-trisubstituted imidazoles and 1,2-disubstituted benzimidazoles under solvent free conditions and evaluation of their antibacterial study. RSC Adv. 2015, 5, 75533-75546, https://doi.org/10.1039/c5ra13891d.

40. Nandi, S.; Singh, S.K.; Mullangi, D.; Illathvalappil, R.; George, L.; Vinod, C.P.; Kurungot, S.; Vaidhyanathan, R. Low Band Gap Benzimidazole COF Supported $\mathrm{Ni}_{3} \mathrm{~N}$ as Highly Active OER Catalyst. Adv. Energy Mater. 2016, 6, https://doi.org/10.1002/aenm.201601189.

41. Kimura, K.; Gong, J.; Kohama, S.I.; Yamazaki, S.; Uchida, T.; Kimura, K. Poly(2,5-benzimidazole) nanofibers prepared by reaction-induced crystallization. Polym. J. 2010, 42, 375-382, https://doi.org/10.1038/pj.2010.20.

42. Rodríguez-Castillo, M.; Lugo-Preciado, G.; Laurencin, D.; Tielens, F.; van der Lee, A.; Clément, S.; Guari, Y.; López-de-Luzuriaga, J.M.; Monge, M.; Remacle, F.; Richeter, S. Back Cover: Experimental and Theoretical Study of the Reactivity of Gold Nanoparticles Towards Benzimidazole-2-ylidene Ligands (Chem. Eur. J. 30/2016). Chem. - A Eur. J. 2016, 22, https://doi.org/10.1002/chem.201602146.

43. Ganesh Babu, S.; Karvembu, R. CuO nanoparticles: A simple, effective, ligand free, and reusable heterogeneous catalyst for N -arylation of benzimidazole. Ind. Eng. Chem. Res. 2011, 50, 9594-9600, https://doi.org/10.1021/ie200797e.

44. El-Sayed, A.A.; A.M. Khalil, M.; El-Shahat, N.Y.; Khaireldin, R.S.T. Antimicrobial activity of PVCpyrazolone-silver nanocomposites. J. Macromolec. Sci. A 2016, 50, 346-353, https://doi.org/10.1080/10601325.2016.1166000.

45. Khalil, A.M.; T. Rabie S.T. Antimicrobial behavior and photostability of polyvinyl chloride/1 vinylimidazole nanocomposites loaded with silver or copper nanoparticles. J. Vinyl Addit. Technol. 2017, 23, E25-E33, https://doi.org/10.1002/vnl.21588.

46. Khalil, A.M.; Abdel-Monem, R.A.; Darwesh, O.M.; Hashim, A.I.; Nada, A.A.; Rabie, S.T. Synthesis, characterization, and evaluation of antimicrobial activities of chitosan and carboxymethyl chitosan schiffbase/silver nanoparticles. Journal of Chemistry 2017, 2017, https://doi.org/10.1155/2017/1434320.

47. El-Sayed, A.A.; El-Saidi, M.; Khattab, R. Unexpected Reactions of Azido-p-Benzoquinone Derivatives towards Lawesson's Reagent \& Molecular Docking Study as a promising anticancer agent. Egypt. J. Chem. 2019, 62, 315-326, https://doi.org/10.21608/ejchem.2019.17488.2074.

48. El-Sayed, A.A.; Amr, A.; Kamel, O.M.H.M.; El-Saidi, M.M.T.; Abdelhamid, A.E. Eco-friendly fabric modification based on AgNPs@ Moringa for mosquito repellent applications. Cellulose 2020, 27, 84298442, https://doi.org/10.1007/s10570-020-03355-8.

49. Abdel-Monem, R.A.; Khalil, A.M.; Darwesh, O.M.; Hashim, A.I.; Rabie, S.T. Antibacterial properties of carboxymethyl chitosan Schiff-base nanocomposites loaded with silver nanoparticles. J. Macromolec. Sci. A 2020, 57, 145-55, https://doi.org/10.1080/10601325.2019.1674666.

50. Shoueir, K.; Wassel, A.R.; Ahmed, M.K.; El-Naggar, M.E. Encapsulation of extremely stable polyaniline onto Bio-MOF: Photo-activated antibacterial and depletion of ciprofloxacin from aqueous solutions. J. Photochem. Photobiol. A 2020, 400, https://doi.org/10.1016/j.jphotochem.2020.112703.

51. Shoueir, K.R. Green microwave synthesis of functionalized chitosan with robust adsorption capacities for $\mathrm{Cr}$ (VI) and/or RHB in complex aqueous solutions. Environ. Sci. Pollut. Res.; 2020, 27, 33020-3303. https://doi.org/10.1007/s11356-020-09341-8.

52. Abdelbar, M.F.; Shams, R.S.; Morsy, O.M.; Hady, M.A.; Shoueir, K.; Abdelmonem, R. Highly ordered functionalized mesoporous silicate nanoparticles reinforced poly (lactic acid) gatekeeper surface for infection treatment. Int. J. Biol. Macromol. 2020, https://doi.org/10.1016/j.ijbiomac.2020.04.119.

53. Shoueir, K.R.; El-Desouky, N.; Rashad, M.M.; Ahmed, M.K.; Janowska, I.; El-Kemary, M. Chitosan basednanoparticles and nanocapsules: Overview, physicochemical features, applications of a nanofibrous scaffold, and bioprinting. Int. J. Biol. Macromol. 2021, 167, 1176-1197, https://doi.org/10.1016/j.ijbiomac.2020.11.072. 
54. Rao, A.; Chimirri, A.; De Clercq, E.; Monforte, A.M.; Monforte, P.; Pannecouque, C.; Zappalà, M. Synthesis and anti-HIV activity of 1-(2,6-difluorophenyl)-1H,3H-thiazolo[3,4-a]benzimidazole structurally-related 1,2-substituted benzimidazoles. Farmaco. 2002, 57, 819-823, https://doi.org/10.1016/S0014827X(02)01300-9.

55. Barreca, M.L.; Balzarini, J.; Chimirri, A.; Clercq, E.D.; Luca, L.D.; Höltje, H.D.; Höltje, M.; Monforte, A.M.; Monforte, P.; Pannecouque, C.; Rao, A. Design, synthesis, structure-activity relationships, and molecular modeling studies of 2,3-diaryl-1,3-thiazolidin-4-ones as potent anti-HIV agents. J. Med. Chem. 2002, 45, 5410-5413, https://doi.org/10.1021/JM020977+.

56. Chimirri, A.; Grasso, S.; Monforte, A.M.; Monforte, P.; Rao, A.; Zappalà, M.; Bruno, G.; Nicolò, F.; Pannecouque, C.; Witvrouw, M.; De Clercq, E. Synthesis, structure and in vitro anti-human immunodeficiency virus activity of novel 3-methyl-1H,3H-thiazolo[3,4-a]benzimidazoles. Antivir. Chem. Chemother. 1998, 9, 431-438, https://doi.org/10.1177/095632029800900507.

57. Chimirri, A.; Grasso, S.; Molica, C.; Monforte, A.-M.; Monforte, P.; Zappalà, M.; Bruno, G.; Nicolò, F.; Witvrouw, M.; Jonckeere, H.; Balzarini, J.; De Clercq, E. Structural Features and Anti-Human Immunodeficiency Virus (HIV) Activity of the Isomers of 1-(2',6'-Difluorophenyl)-1 $H, 3 H$-Thiazolo[3,4$a$ ]Benzimidazole, a Potent Non-Nucleoside HIV-1 Reverse Transcriptase Inhibitor. Antivir. Chem. Chemother. 1997, 8, 363-370, https://doi.org/10.1177/095632029700800409.

58. Khalifa, M.E.; Gobouri, A.A.; Kabli, F.M.; Altalhi, T.A.; Almalki, A.S.; Elemshaty, A.M. Synthesis and Pharmacological Investigations of Novel Pyrazolyl and Hydrazonoyl Cyanide Benzimidazole Entities. $J$. Heterocycl. Chem. 2019, 56, 1426-1436, https://doi.org/10.1002/jhet.3522.

59. Tahlan, S.; Kumar, S. Narasimhan, B. Pharmacological significance of heterocyclic 1 H-benzimidazole scaffolds: a review. BMC Chem. 2019, 13, 1-21, https://doi.org/10.1186/s13065-019-0625-4.

60. Ishida, T.; Suzuki, T.; Hirashima, S.; Mizutani, K.; Yoshida, A.; Ando, I.; Ikeda, S.; Adachi, T.; Hashimoto, H. Benzimidazole inhibitors of hepatitis C virus NS5B polymerase: Identification of 2-[(4diarylmethoxy)phenyl]-benzimidazole. Bioorganic Med. Chem. Lett. 2006, 16, 1859-1863, https://doi.org/10.1016/j.bmcl.2006.01.032.

61. Hirashima, S.; Suzuki.; T.; Ishida, T.; Noji, S.; Yata, S.; Ando, I.; Komatsu M.; Ikeda, S.; Hashimoto H. Benzimidazole derivatives bearing substituted biphenyls as hepatitis C virus NS5B RNA-dependent RNA polymerase inhibitors: Structure-activity relationship studies and identification of a potent and highly selective inhibitor JTK-109. J. Med. Chem. 2006, 49, 4721-4736, https://doi.org/10.1021/jm060269e.

62. Hirashima, S.; Oka, T.; Ikegashira, K.; Noji, S.; Yamanaka, H.; Hara, Y.; Goto, H.; Mizojiri, R.; Niwa, Y.; Noguchi, T.; Ando, I.; Ikeda, S.; Hashimoto, H. Further studies on hepatitis C virus NS5B RNA-dependent RNA polymerase inhibitors toward improved replicon cell activities: Benzimidazole and structurally related compounds bearing the 2-morpholinophenyl moiety. Bioorg. Med. Chem. Lett. 2007, 17, 3181-3186, https://doi.org/10.1016/j.bmcl.2007.03.027.

63. Beaulieu, P.L.; Bös, M.; Bousquet, Y.; DeRoy, P.; Fazal, G.; Gauthier, J.; Gillard, J.; Goulet, S.; McKercher, G.; Poupart, M.-A.; Valois, S.; Kukolj, G. Non-nucleoside inhibitors of the hepatitis C virus NS5B polymerase: discovery of benzimidazole 5-carboxylic amide derivatives with low-nanomolar potency. Bioorg. Med. Chem. Lett. 2004, 14, 967-971, https://doi.org/10.1016/j.bmcl.2003.12.032.

64. Beaulieu, P.L.; Bös, M.; Bousquet, Y.; Fazal, G.; Gauthier, J.; Gillard, J.; Goulet, S.; LaPlante, S.; Poupart, M.A.; Lefebvre, S.; McKercher, G.; Pellerin, C.; Austel, V.; Kukolj, G. Non-nucleoside inhibitors of the hepatitis C virus NS5B polymerase: Discovery and preliminary SAR of benzimidazole derivatives. Bioorganic Med. Chem. Lett. 2004, 14, 119-124, https://doi.org/10.1016/j.bmcl.2003.10.023.

65. Lee, J.H.; Lee, S.; Park, M.Y.; Myung, H. Characterization of thiobarbituric acid derivatives as inhibitors of hepatitis C virus NS5B polymerase. Virol. J. 2011, 8, https://doi.org/10.1186/1743-422X-8-18.

66. Beaulieu, P.L.; Gillard, J.; Bykowski, D.; Brochu, C.; Dansereau, N.; Duceppe, J.S.; Haché, B.; Jakalian, A.; Lagacé, L.; LaPlante, S.; McKercher, G.; Moreau, E.; Perreault, S.; Stammers, T.; Thauvette, L.; Warrington, J.; Kukolj, G. Improved replicon cellular activity of non-nucleoside allosteric inhibitors of HCV NS5B polymerase: From benzimidazole to indole scaffolds. Bioorganic Med. Chem. Lett. 2006, 16, 4987-4993, https://doi.org/10.1016/j.bmcl.2006.07.074.

67. Evers, D.L.; Komazin, G.; Shin, D.; Hwang, D.D.; Townsend, L.B.; Drach, J.C. Interactions among antiviral drugs acting late in the replication cycle of human cytomegalovirus. Antiviral Res. 2002, 56, 61-72, https://doi.org/10.1016/S0166-3542(02)00094-3.

68. Biron, K.K. Antiviral drugs for cytomegalovirus diseases. Antiviral Res. 2006, 71, 154-163, https://doi.org/10.1016/j.antiviral.2006.05.002.

69. Townsend, L.B.; Gudmundsson, K.S.; Daluge, S.M.; Chen, J.J.; Zhu, Z.; Koszalka, G.W.; Boyd, L.; Chamberlain, S.D.; Freeman, G.A.; Biron, K.K.; Drach, J.C. Studies designed to increase the stability and antiviral activity (HCMV) of the active benzimidazole nucleoside, TCRB. Nucleosides and Nucleotides, Marcel Dekker Inc. 1999, 18, 509-519, https://doi.org/10.1080/15257779908041486.

70. Devivar, R.V.; Kawashima, E.; Revankar, G.R.; Breitenbach, J.M.; Kreske, E.D.; Drach, J.C.; Townsend, L.B. Benzimidazole Ribonucleosides: Design, Synthesis, and Antiviral Activity of Certain 2-(Alkylthio)and 2-(Benzylthio)-5,6-dichloro-1-( $\beta$-D-ribofuranosyl)benzimidazoles. J. Med. Chem. 1994, 37, 29422949, https://doi.org/10.1021/jm00044a015. 
71. Garuti, L.; Roberti, M.; Gentilomi, G. Synthesis and antiviral assays of some benzimidazole nucleosides and acyclonucleosides. Farmaco. 2001, 56, 815-819, https://doi.org/10.1016/S0014-827X(01)01164-8.

72. Cheng, J.; Xie J.; Luo, X. Synthesis and antiviral activity against Coxsackie virus B3 of some novel benzimidazole derivatives. Bioorganic Med. Chem. Lett. 2005, 15, 267-269, https://doi.org/10.1016/j.bmcl.2004.10.087.

73. Garuti, L.; Roberti, M.; Cermelli, C. Synthesis and antiviral activity of some Nbenzenesulphonylbenzimidazoles. Bioorganic Med. Chem. Lett. 1999, 9, 2525-2530, https://doi.org/10.1016/S0960-894X(99)00429-1.

74. Starčević, K.; Kralj, M.; Ester, K.; Sabol, I.; Grce, M.; Pavelić, K.; Karminski-Zamola, G. Synthesis, antiviral and antitumor activity of 2-substituted-5-amidino-benzimidazoles. Bioorganic Med. Chem. 2007, 15, 44194426, https://doi.org/10.1016/j.bmc.2007.04.032.

75. Victor, F.; Brown, T.J.; Campanale, K.; Heinz, B.A.; Shipley, L.A.; Su, K.S.; Tang, J.; Vance, L.M.; Spitzer, W.A. Synthesis, antiviral activity, and biological properties of vinylacetylene analogs of enviroxime. J. Med. Chem. 1997, 40, 1511-1518, https://doi.org/10.1021/jm960718i.

76. Kanwal, A.; Ahmad, M.; Aslam, S.; Naqvi, S.A.R. Saif, M.J. Recent advances in antiviral benzimidazole derivatives: a mini review. Pharmaceutical Chemistry Journal 2019, 53, 179-187, https://doi.org/10.1007/s11094-019-01976-3.

77. Pribut, N.; Kaiser, T.M.; Wilson, R.J.; Jecs, E.; Dentmon, Z.W.; Pelly, S.C.; Sharma, S.; Bartsch III, P.W.; Burger, P.B.; Hwang, S.S.; Le, T. Accelerated Discovery of Potent Fusion Inhibitors for Respiratory Syncytial Virus. ACS infectious diseases 2020, 6, 922-929, https://doi.org/10.1021/acsinfecdis.9b00524.

78. Tebbe, M.; Jensen, C.; Aspitzer, W.; Franklin, R.; George, M.; Phillips, D. The effects of antirhino- and enteroviral vinylacetylene benzimidazoles on cytochrome P450 function and hepatic porphyrin levels in mice. Antiviral Res. 1999, 42, 25-33, https://doi.org/10.1016/S0166-3542(99)00013-3.

79. Chen, J.Q.; Liu, X.; Guo, J. Dong, Z.B.; A Chemoselective and Desulfurative Chan-Lam Coupling: C-N Bond Formation between Benzimidazoline-2-Thiones and Arylboronic Acids. European Journal of Organic Chemistry 2020, 16, 2414-2424, https://doi.org/10.1002/ejoc.202000075.

80. Yu, K.-L.; Wang, X.A.; Civiello, R.L.; Trehan, A.K.; Pearce, B.C.; Yin, Z.; Combrink, K.D.; Gulgeze, H.B.; Zhang, Y.; Kadow, K.F.; Cianci, C.W.; Clarke, J.; Genovesi, E.V.; Medina, I.; Lamb, L.; Wyde, P.R.; Krystal, M.; Meanwell, N.A. Respiratory syncytial virus fusion inhibitors. Part 3: Water-soluble benzimidazol-2-one derivatives with antiviral activity in vivo. Bioorg. Med. Chem. Lett. 2006, 16, 11151122, https://doi.org/10.1016/j.bmcl.2005.11.109.

81. Combrink, K.D.; Gulgeze, H.B.; Thuring, J.W.; Yu, K.L.; Civiello, R.L.; Zhang, Y.; Pearce, B.C.; Yin, Z.; Langley, D.R.; Kadow, K.F.; Cianci, C.W.; Li, Z.; Clarke, J.; Genovesi, E.V.; Medina, I.; Lamb, L.; Yang, Z.; Zadjura, L.; Krystal, M.; Meanwell, N.A. Respiratory syncytial virus fusion inhibitors. Part 6: An examination of the effect of structural variation of the benzimidazol-2-one heterocycle moiet. Bioorganic Med. Chem. Lett. 2007, 17, 4784-4790, https://doi.org/10.1016/j.bmcl.2007.06.065.

82. Andries, K.; Moeremans, M.; Gevers, T.; Willebrords, R.; Sommen, C.; Lacrampe, J.; Janssens, F.; Wyde, P.R. Substituted benzimidazoles with nanomolar activity against respiratory syncytial virus. Antiviral Res. 2003, 60, 209-219, https://doi.org/10.1016/j.antiviral.2003.07.004.

83. Andries, K.; Moeremans, M.; Gevers, T.; Willebrords, R.; Sommen, C.; Lacrampe, J.; Janssens, F.; Wyde, P.R. Substituted benzimidazoles with nanomolar activity against respiratory syncytial virus. Antiviral Res. 2003, 60, 209-219, https://doi.org/10.1016/j.antiviral.2003.07.004.

84. Palma, A.M.D.; Heggermont, W.; Leyssen, P.; Pürstinger, G.; Wimmer, E.; De Clercq, E.; Rao, A.; Monforte, A.M.; Chimirri, A.; Neyts, J. Anti-enterovirus activity and structure-activity relationship of a series of 2,6-dihalophenyl-substituted 1H,3H-thiazolo[3,4-a]benzimidazoles. Biochem. Biophys. Res. Commun. 2007, 353, 628-632, https://doi.org/10.1016/j.bbrc.2006.12.063.

85. Alper, S.; Arpaci, Ö.T.; Aki, E.S, Yalçin, I. Some new bi- and ter-benzimidazole derivatives as topoisomerase I inhibitors. Farmaco. 2003, 58, 497-507, https://doi.org/10.1016/S0014-827X(03)00042-9.

86. Sun, Q.; Gatto, B.; Yu, C.; Liu, A.; Liu, L.F.; LaVoie, E.J. Synthesis and Evaluation of Terbenzimidazoles as Topoisomerase I Inhibitors. J. Med. Chem. 1995, 38, 3638-3644, https://doi.org/10.1021/jm00018a024.

87. Sun, Q.; Gatto, B.; Yu, C.; Liu, A.; Liu, L.F.; LaVoie, E.J. Structure activity of topoisomerase i poisons related to hoechst 33342. Bioorganic Med. Chem. Lett. 1994, 4, 2871-2876, https://doi.org/10.1016/S0960894X(01)80831-3.

88. Corbett, A.H.; Guerry, P.; Pflieger, P.; Osheroff, N. A pyrimido[1,6-a]benzimidazole that enhances DNA cleavage mediated by eukaryotic topoisomerase II: A novel class of topoisomerase II-targeted drugs with cytotoxic potential, Antimicrob. Agents Chemother. 1993, 37, 2599-2605, https://doi.org/10.1128/AAC.37.12.2599.

89. Gravatt, G.L.; Baguley, B.C.; Wilson, W.R.; Denny, W.A. DNA-Directed Alkylating Agents. 6. Synthesis and Antitumor Activity of DNA Minor Groove-Targeted Aniline Mustard Analogues of Pibenzimol (Hoechst 33258). J. Med. Chem. 1994, 37, 4338-4345, https://doi.org/10.1021/jm00051a010.

90. Skibo, E.B.; Schulz, W.G. Pyrrolo[1,2-a]benzimidazole-Based Aziridinyl Quinones. A New Class of DNA Cleaving Agent Exhibiting $G$ and A Base Specificity. J. Med. Chem. 1993, 36, 3050-3055, https://doi.org/10.1021/jm00073a002. 
91. Schulz, W.G.; Islam, I.; Skibo, E.B. Pyrrolo[1,2- $\alpha$ benzimidazole-Based Quinones and Iminoquinones. The Role of the 3-Substituent on Cytotoxicity. J. Med. Chem. 1995, 38, 109-118, https://doi.org/10.1021/jm00001a016.

92. Skibo, E.B.; Islam, I.; Heileman, M.J.; Schulz, W.G. Structure-Activity Studies of Benzimidazole-Based DNA-Cleaving Agents. Comparison of Benzimidazole, Pyrrolobenzimidazole, and Tetrahydropyridobenzimidazole Analogues. J. Med. Chem. 1994, 37, 78-92, https://doi.org/10.1021/jm00027a010.

93. Boruah, R.C.; Skibo, E.B. A Comparison of the Cytotoxic and Physical Properties of Aziridinyl Quinone Derivatives Based on the Pyrrolo[1,2-a]benzimidazole and Pyrrolo[1,2-a]indole Ring Systems. J. Med. Chem. 1994, 37, 1625-1631, https://doi.org/10.1021/jm00037a013.

94. Palmer, B.D.; Kraker, A.J.; Hait, B.G.; Panopoulos, A.D.; Panek, R.L.; Batley, B.L.; Lu, G.H.; TrumppKallmeyer, S.; Showalter, H.D.H.; Denny, W.A. Structure-activity relationships for 5-substituted 1phenylbenzimidazoles as selective inhibitors of the platelet-derived growth factor receptor. J. Med. Chem. 1999, 42, 2373-2382, https://doi.org/10.1021/jm980658b.

95. Katritzky, A.R.; Dobchev, D.A.; Fara, D.C.; Karelson, M. QSAR studies on 1-phenylbenzimidazoles as inhibitors of the platelet-derived growth factor. Bioorganic Med. Chem. 2005, 13, 6598-6608, https://doi.org/10.1016/j.bmc.2005.06.067.

96. Velaparthi, U.; Liu, P.; Balasubramanian, B.; Carboni, J.; Attar, R.; Gottardis, M.; Li, A.; Greer, A.; Zoeckler, M.; Wittman, M.D.; Vyas, D. Imidazole moiety replacements in the 3-(1H-benzo[d]imidazol-2yl)pyridin-2(1H)-one inhibitors of insulin-like growth factor receptor-1 (IGF-1R) to improve cytochrome P450 profile. Bioorg. Med. Chem. Lett. 2007, 17, 3072-3076, https://doi.org/10.1016/j.bmcl.2007.03.048.

97. Saulnier, M.G.; Frennesson, D.B.; Wittman, M.D.; Zimmermann, K.; Velaparthi, U.; Langley, D.R.; Struzynski, C.; Sang, X.; Carboni, J.; Li, A.; Greer, A.; Yang, Z.; Balimane, P.; Gottardis, M.; Attar, R.; Vyas, D. 2-(1H-Imidazol-4-yl)ethanamine and 2-(1H-pyrazol-1-yl)ethanamine side chain variants of the IGF-1R inhibitor BMS-536924. Bioorg. Med. Chem. Lett. 2008, 18, 1702-1707, https://doi.org/10.1016/j.bmcl.2008.01.049.

98. Wittman, M.; Carboni, J.; Attar, R.; Balasubramanian, B.; Balimane, P.; Brassil, P.; Beaulieu, F.; Chang, C.; Clarke, W.; Dell, J.; Eummer, J.; Frennesson, D.; Gottardis, M.; Greer, A.; Hansel, S.; Hurlburt, W.; Jacobson, B.; Krishnananthan, S.; Lee, F.Y.; Li, A.; Lin, T.A.; Liu, P.; Ouellet, C.; Sang, X.; Saulnier, M.G.; Stoffan, K.; Sun, Y.; Velaparthi, U.; Wong, H.; Yang, Z.; Zimmermann, K.; Zoeckler, M.; Vyas, D. Discovery of a 1H-benzoimidazol-2-yl)-1H-pyridin-2-one (BMS-536924) inhibitor of insulin-like growth factor I receptor kinase with in vivo antitumor activity. J. Med. Chem. 2005, 48, 5639-5643, https://doi.org/10.1021/jm050392q.

99. Pagano, M.A.; Andrzejewska, M.; Ruzzene, M.; Sarno, S.; Cesaro, L.; Bain, J.; Elliott, M.; Meggio, F.; Kazimierczuk, Z.; Pinna, L.A. Optimization of protein kinase CK2 inhibitors derived from 4,5,6,7tetrabromobenzimidazole. J. Med. Chem. 2004, 47, 6239-6247, https://doi.org/10.1021/jm049854a.

100. Pagano, M.A.; Meggio, F.; Ruzzene, M.; Andrzejewska, M.; Kazimierczuk, Z.; Pinna, L.A. 2Dimethylamino-4,5,6,7-tetrabromo-1H-benzimidazole: A novel powerful and selective inhibitor of protein kinase CK2. Biochem. Biophys. Res. Commun. 2004, 321, 1040-1044, https://doi.org/10.1016/j.bbrc.2004.07.067.

101. McClure, K.J.; Huang, L.; Arienti, K.L.; Axe, F.U.; Brunmark, A.; Blevitt, J.; Breitenbucher, J.G. Novel non-benzimidazole chk2 kinase inhibitors. Bioorg. Med. Chem. Lett. 2006, 16, 1924-1928, https://doi.org/10.1016/j.bmcl.2005.12.096.

102. Neff, D.K.; Lee-Dutra, A.; Blevitt, J.M.; Axe, F.U.; Hack, M.D.; Buma, J.C.; Rynberg, R.; Brunmark, A.; Karlsson, L.; Breitenbucher, J.G. 2-Aryl benzimidazoles featuring alkyl-linked pendant alcohols and amins as inhibitors of checkpoint kinase Chk2. Bioorganic Med. Chem. Lett. 2007, 17, 6467-6471, https://doi.org/10.1016/j.bmcl.2007.09.098.

103. Arienti, K.L.; Brunmark, A.; Axe, F.U.; McClure, K.; Lee, A.; Blevitt, J.; Neff, D.K.; Huang, L.; Crawford, S.; Pandit, C.R.; Karlsson, L.; Breitenbucher, J.G. Checkpoint kinase inhibitors: SAR and radioprotective properties of a series of 2-arylbenzimidazoles. J. Med. Chem. 2005, 48, 1873-1885, https://doi.org/10.1021/jm0495935.

104. Hajduk, P.J.; Boyd, S.; Nettesheim, D.; Nienaber, V.; Severin, J.; Smith, R.; Davidson, D.; Rockway, T.; Fesik, S.W. Identification of novel inhibitors of urokinase via NMR-based screening. J. Med. Chem. 2000, 43, 3862-3866, https://doi.org/10.1021/jm0002228.

105. Torrence, P.F. Antiviral Drug Discovery for Emerging Diseases and Bioterrorism Threats. John Wiley \& Sons, Inc.; Hoboken, NJ, USA 2005, https://doi.org/10.1002/0471716715.

106. Stamper, I.J.; Byrne, H.M.; Owen, M.R.; Maini, P.K. Modelling the role of angiogenesis and vasculogenesis in solid tumour growth. Bull. Math. Biol. 2007, 69, 2737-2772, https://doi.org/10.1007/s11538-007-9253-6.

107. Bain, J.; McLauchlan, H.; Elliott, M.; Cohen, P. The specificities of protein kinase inhibitors: An update. Biochem. J. 2003, 371, 199-204, https://doi.org/10.1042/BJ20021535.

108. Abdullaziz, M.A.; Abdel-Mohsen, H.T.; El Kerdawy, A.M.; Ragab, F.A.F.; Ali, M.M.; Abu-bakr, S.M.; Girgis, A.S.; El Diwani, H.I. Design, synthesis, molecular docking and cytotoxic evaluation of novel 2- 
furybenzimidazoles as VEGFR-2 inhibitors. Eur. J. Med. Chem. 2017, 136, 315-329, https://doi.org/10.1016/j.ejmech.2017.04.068.

109. Abdel-Hafez, A.A.M. Benzimidazole condensed ring systems: New synthesis and antineoplastic activity of substituted 3,4-dihydro- and 1,2,3,4-tetrahydro-benzo[4,5]imidazo[1, 2-a]pyrimidine derivatives. Arch. Pharm. Res. 2007, 30 678-684, https://doi.org/10.1007/BF02977627.

110. Ramla, M.M.; Omar, M.A.; El-Khamry, A.M.M.; El-Diwani, H.I. Synthesis and antitumor activity of 1substituted-2-methyl-5-nitrobenzimidazoles, Bioorganic Med. Chem. 2006, 14, 7324-7332, https://doi.org/10.1016/j.bmc.2006.06.033.

111. Ramla, M.M.; Omar, M.A.; Tokuda, H.; El-Diwani, H.I. Synthesis and inhibitory activity of new benzimidazole derivatives against Burkitt's lymphoma promotion. Bioorganic Med. Chem. 2007, 15, 64896496, https://doi.org/10.1016/j.bmc.2007.04.010.

112. El-Naem, S.I.; El-Nzhawy, A.O.; El-Diwani, H.I.; Abdel Hamid, A.O. Synthesis of 5-substituted 2methylbenzimidazoles with anticancer activity. Arch. Pharm. (Weinheim) 2003, 336, 7-17, https://doi.org/10.1002/ardp.200390005. 